\title{
The Revival of Interest in the Russian Past in the Soviet Union
}

Students of Russia and the Soviet Union scarcely need to be reminded that the October Revolution did not resolve the long-standing question of Russia's cultural position vis-à-vis the West, if indeed it could reasonably have been expected to do so. Russia's national destiny, a theme that has figured prominently in the Russian cultural tradition at least since Metropolitan Ilarion's sermon "On Law and Grace" in the eleventh century, has remained a theoretical and practical problem for the builders of proletarian internationalism in the USSR, and it has been a frequent source of conflict with the non-Russian minorities in the state to the present day. The events and atmosphere created by the Twentieth Party Congress in 1956 seem to have provided the opportunity for latent nationalism to assert itself in the 1960s. In nearly every field of endeavor, in every branch of culture, there have been noticeable efforts to rediscover the past and to elucidate the essence of the "Russian soul." What follows is not an exhaustive survey of all these developments but rather an attempt to initiate discussion on the topic. I shall try to indicate something of the scope of this "culturalist" movement," and in particular I hope to show that although its roots in each branch of culture can be traced to the efforts of a great many distinguished scholars in the Soviet Union, the significance of "culturalism" far transcends the important work of the academies.

There are at least three levels of interest involved in culturalism: the scholarly, the popular, and the faddish. In many respects it is the popular groupalthough "popularizing" might be more appropriate-that is of greatest interest. In using this term I do not wish to impugn the motives of those interested in Russian culture who are-at least at the onset of what often has become a passion-amateurs. Indeed, many of the activities described here have been carried out by professionals in every sense of the word. It is in their intentions

1. The terms "culturalist" and "culturalism" have been used by those writing on Chinese history in the past but in a different sense from that which I propose here. The terms seem appropriate in that they are narrower than nationalism, broader than chauvinism, are not associated with other similar phenomena in Russian history, and rather accurately define the movement about which I am writing here. Culturalism has at its base Russian culture, whether haute culture or popular. 
that the best representatives of this group differ from the scholars, but there is not always a clear-cut distinction to be drawn. Andrei Volkonsky and the group of singers known as the Madrigals he has organized to perform pre-Petrine church music, which Volkonsky has himself searched out and decoded, could scarcely be termed amateurs, but their purpose is not primarily scholarly. ${ }^{2}$

It is from the popularizers of the culturalist movement that an intellectual framework emerged. Based on the very substantial fruits of Soviet scholarship and to a lesser extent on the faddists, this group began to present a somewhat tentative and cautious program of national spiritual renewal on a basis of what has variously been termed chauvinism, Slavophilism, patriotism, and extreme nationalism. It consists of two closely associated ideas: that Rus', particularly before Peter I, had a spiritual strength and integrity lacking in twentieth-century Soviet Russia; and that the only living connection between Old Russia and the present is to be found outside the asphalt jungle of the cities in the countryside (this is the point of view of the ruralists, the derevenshchiki). The culturalists' public discussion brought forth a reaction from the more orthodox elements in Soviet society, as they could easily have expected. It is interesting for the observer to note just who sided with whom in the ensuing debate, and I have tried to indicate the main adversaries and their positions in this paper.

Finally, I have attempted to point out some possible reasons for the tremendous interest in Russia's past that has nurtured culturalism, although I have avoided some interesting aspects of this question, such as the role of the military in fostering it, simply because $I$ am totally unqualified to raise them. What does seem clear is that culturalism has broad appeal, if perhaps limited active support in the Soviet Union.

The talented Soviet writer, Efim Dorosh, has written that "the Russian past has become a fashion.... But a fashion, like foam on water betraying the activity going on in its depths, marks certain deep social processes."3 Much of the interest in Russia's past is simply a result of fashion. One is not impressed with the depth of analysis of such writers as the anonymous author of these lines which appeared in Molodaia gvardiia in 1968: "Precisely the inherent strength of the Novgorod land turned out to be preservatory for all the Russian land when the invaders from the East fell upon it. The merit then was not only that the local population did not surrender to the enemy and did not permit the invasion. There [in Novgorod] they saved from ruin and fall European culture, the European peoples, and their complex and high civilization." 4 Such exuber-

2. See Georgie Anne Geyer, "A New Quest for the Old Russia," Saturday Review, Dec. 25, 1971, p. 16.

3. Efim Dorosh, "Obrazy Rossii," Nozyi mir, 1969, no. 3, p. 182.

4. "Tysiacheletnie korni russkoi kul'tury," Molodaia gvardiia, 1968, no. 9, p. 254. 
ance, though not rare, is completely overshadowed by the really outstanding contributions to the study of Russia's past that have appeared in recent years and by serious attempts to make Russia's cultural heritage accessible to the masses of the Soviet people.

Architectural historians have been particularly prominent in the revival of interest in Russia's past. Unquestionably, the monumental two-volume work by N. N. Voronin, Zodchestvo severo-vostochnoi Rusi XII-XV vekov (The Architecture of Northeast Rus' in the XII-XV Centuries), which appeared in 1961, set particularly high standards. Such works, in limited editions (twentyfive hundred copies of Voronin's work were published), have been accompanied by popular guides to the architectural treasures of Russia. Voronin's guide to the architecture of the Vladimir-Suzdal region was issued in a second edition of thirty thousand copies in 1965. The following year, M. K. Karger's similar guide for Novgorod came out in fifty thousand copies, and M. A. Ilin's Podmoskov'e (Moscow and Its Surroundings) in seventy-five thousand copies.

The relatively large editions of these guidebooks are one indication of the burgeoning interest in these places on the part of ordinary Soviet citizens. As Dorosh puts it, "Perhaps the most indisputable evidence for the existence of the aforementioned fashion is that Moscow 'ladies,' a category rather more psychological and timeless than social, have begun to decorate their apartments with icons, folk pottery from Gorodetsk, or with Northern Dvina distaves, referring to a trip to Rostov-Iaroslavsky or Suzdal with condescending disdain just as fifteen years ago they referred [with condescension] to the Black Sea coast while vacationing on the Riga sea front-they travel only to Kizhi or Solovki."' Moscow and Leningrad youths also are prominent turisty, and may be seen in all parts of northern Russia with their cameras and beards, searching for Russia's lost "soul." But not all of the tourists visiting the more remote parts of the country are amateurs, by any means. Continuing an old tradition, various scientific and scholarly expeditions scour the countryside for icons, old books, manuscripts, and examples of folk art and handicraft. Such journals as Arkheologicheskii ezhegodnik and Trudy otdela drevnerusskoi literatury report on the considerable accomplishments of these expeditions, while in a more popular vein Novyi mir, for instance, has published essays on their findings. ${ }^{6}$

These expeditions have resulted in the recovery of much more than distaves and folk pottery. As writer-collectors such as Vladimir Soloukhin have related, ${ }^{7}$ many excellent examples of Old Russian iconography have been pre-

5. Dorosh, “Obrazy Rossii," p. 182.

6. N. Tarasenkova, "Za vologodskoi starinoi . . . : Ocherk," Novyi mir, 1969, no. 4, pp. $105-20$.

7. See particularly Vladimir Soloukhin, "Pis'ma iz Russkogo muzeia," in Molodaia gvardiia, 1966, nos. 9 and 10, and "Chernye doski : Zapiski nachinaiushchego kollektsionera," Moskva, 1969, no. 1, pp. 129-87. 
served in this way. Indeed, the search for icons is one of the most popular activities connected with the revival of interest in Russia's past. It is difficult for someone without access to the private collections-for that is where most of the new discoveries are apparently housed at the present time-to judge the artistic merit of the discoveries or of their restoration, although the Rublev Museum in Moscow has some excellent, very old icons made accessible to the public in just this way. Those interested in the subject will have their appetites whetted by a recent issue of some twenty-four colored slides by Novosti Press Agency entitled simply "Russian Icons: New Discoveries." The icons in this collection are dated from the thirteenth through the eighteenth century. (Series of slides have recently been issued of the architectural monuments of VladimirSuzdal, the icons of Novgorod and Suzdal, and the icons attributed to Andrei Rublev, for instance. One suspects that these may largely be intended for foreign tourists.)

A large number of books devoted to Russian iconography have been published since 1960. These include V. N. Lazarev's Andrei Rublev $i$ ego shkola (Andrei Rublev and His School, 1966), Novgorodskaia ikonopis' (Novgorod Iconography, 1969), M. V. Alpatov's Pamiatnik drevnerusskoi zhivopisi kontsa $X V$ veka: Ikona "Apokalipsis" Uspenskogo sobora Moskovskogo Kremlia ( $A$ Monument of Old Russian Art: The Icon of "The Apocalypse" of the Cathedral of the Dormition of the Moscow Kremlin, 1964), and M. A. Ilin's Zagorsk: Troitse-Sergieva lavra (Zagorsk: Trinity-Sergius Monastery, 1967). Two books on Trinity-Sergius Monastery depict the icon collections there, together with the architecture of the monastery, in a historical perspective: Trinity-Sergius Monastery by N. N. Voronin and V. V. Kostochkin (1967), and I. V. Trofimov's Pamiatniki arkhitektury Troitse-Sergievoi lavry (Architectural Monuments of Trinity-Sergius Monastery, 1961).

Therc has also been an excellent book published on the sculpture in IurievPolsky, G. K. Vagner's Mastera drevnerusskoi skul'ptury (Masters of Old Russian Sculpture, 1966), as well as one on the wooden sculptures of Perm, N. N. Serebrennikov's Permskaia dereviannaia skul'ptura (The Perm Wooden Sculptures, 1967), and one on those of Vladimir-Suzdal (also by Vagner, 1964). Folk art has not been neglected, as books such as L. Diakonov's on the painted pottery figures of Dymkovo (1964) clearly show. But the greatest credit for making Russia's past art treasures known to the Russian public belongs to scholars including M. V. Alpatov, V. N. Lazarev, O. I. Podobedova, and G. N. Bocharov. Podobedova has published an excellent work, Miniatiury russkikh istoricheskikh rukopisei (Miniatures of Russian Historical Manuscripts, 1965), and Bocharov one called Prikladnoe iskusstvo Novgoroda Velikogo (The Applied Arts of Novgorod the Great, 1969), while Lazarev and Alpatov have continued to publish books, articles, and monographs on art history, ico- 
nography, art and literature, and related topics. In 1967 a two-volume collection of articles by Alpatov was published as Etiudy po istorii russkogo iskusstva (Studies in the History of Russian Art). It contains forty substantial articles ranging from "Russian Art of the Era of the 'Tale of Igor's Campaign'" to "Pushkin's 'Bronze Horseman' " and includes the illustrations of the twentiethcentury artist V. Favorsky.

Near the center of the revival of interest in the Russian past stands the figure of Andrei Rublev, the somewhat mysterious genius of early fifteenthcentury iconography. The number of books and articles that have appeared in the last ten years or so on Rublev and his contemporaries is truly astounding. But interest in Rublev has hardly been restricted to the world of scholarship. A Rublev museum in the former Spas-Andronnikov Monastery, where the artist was buried, was opened in 1964 at the instigation and behest of a group of young students, a magnificent film on the painter (by Andrei Tarkovsky) was produced at roughly the same time (it won the Cannes Festival award but was not re-released in the Soviet Union until 1972; the scenario was published in Iskusstro kino in 1964, nos. 4 and 5), and an exhibition devoted to Rublev and his school has been staged at the Tretiakov Gallery in Moscow. Rublevmonk, ascetic, and artist-has clearly become a central cultural hero in the whole movement.

In 1971 an extraordinary little book was published by "Nauka" in Leningrad, Khudozhestvennoe nasledie drevnei Rusi i sovremennost' (The Artistic Heritage of Ancient Rus' and the Present), by Vera Dmitrievna Likhacheva and her father, the noted specialist in Old Russian literature, Dmitrii Sergeevich Likhachev. The notion that medieval Russian art has close affinities with modern art is given credence by the cover of the book, which juxtaposes a Madonna icon and a painting of a woman by K. S. Petrov-Vodkin, who has himself long been a taboo figure in Soviet art. (Other examples of PetrovVodkin's work in the book illustrate even more clearly the thesis that he was a twentieth-century "iconographer.")

Likhachev has been a leading figure in the rapid development of the study of medieval literature. His Poetika drevnerusskoi literatury (Poetics of Old Russian Literature, 1967) and the volume edited by Ia. S. Lurie, Istoki russkoi belletristiki (Sources of Russian Belles-Lettres, 1970), to which he contributed, mark the first fruits of a trend in medieval literary studies to consider the text primarily as a work of art rather than a historical document with artistic merit. Likhachev's other capital works of this period, the influential Tekstologiia (Textual Criticism, 1962) and the second revised edition of Chelovek $v$ literature drevnei Rusi (Man in the Literature of Ancient Rus', 1970), as well as his editions of texts with modern Russian translation (with L. A. Dmitriev), Izbornik (1969), are all symptomatic of the growing interest in the 
old literature. That the Izbornik was intended for the general public is evident from the size of the edition-three hundred thousand copies. The vast number of publications by such scholars as O. A. Tvorogov, A. N. Robinson, R. P. Dmitrieva, N. A. Kazakova, Ia. S. Lurie, L. A. Dmitriev, A. I. Ivanov, and G. N. Moiseeva testifies to the productivity of those working in the field and to the high quality of the recent scholarship. One example of the influence of this research may be seen in a report published in Molodaia gvardiia in 1968 (no. 9), "The Millennial Roots of Russian Culture," in which the members of the Komsomol, at whom the journal is aimed, are reminded of "the life of Alexander Nevsky (not the hagiographic but the factual one), of the historical account of the lives of Minin and Pozharsky, [and] of the emancipating ideas and edifying witness of Sergii of Radonezh."

Those interested in Russian folk literature have also made their contribution. A new, revised edition of V. Ia. Propp's Morphology of the Folktale and excellent editions of byliny, historical songs, laments, and the like have recently been published, as was B. A. Rybakov's attempt to use folk literature as a source for the early history of Russia, Ancient Rus (1963).

One can easily continue with other examples: in 1963 an excellent recording of the church bells of Rostov the Great by the noted scholar N. N. Pomerantsev (issued by Melodiia); articles complaining of the widespread usage of foreign words in contemporary literary Russian $;{ }^{\theta}$ a history of Russian philosophy from the eleventh through the nineteenth century by A. A. Galaktionov and P. F. Nikandrov (1970) containing chapters on Old Russian philosophy, Dostoevsky, Lavrov, and Soloviev; ${ }^{10}$ an article comparing Pushkin and Rublev ;11 and an article in Ogonek (July 12, 1969) describing an exhibition of samovars in Moscow at which "there was no relief [from the crowd] of visitors at the exhibition." The evidence for a massive, popular movementa search for Russia's past-is overwhelming and could be further elaborated without difficulty. What is interesting, of course, is the very popular nature of the movement. Certainly the scholarship of the late fifties and early sixties has fostered and deepened this interest, but no less certain is the fact that the scope and vigor of the movement caught Soviet authorities somewhat off guard. Not that the revival of interest in Russia's national heritage and the preservation and restoration of artistic and cultural monuments have not been

8. "Tysiacheletnie korni russkoi kul'tury," p. 256.

9. See, for example, K. Iakovlev, "Tiagotenie ili otiagoshchenie?" Molodaia gvardiia, 1968, no. 9, pp. 290-99.

10. This is, in fact, the second edition of Galaktionov and Nikandrov's book. The first, published in 1961, embraced a much more rigid, tendentious, Marxist-Leninist approach.

11. See also the recent book by N. A. Demina, Andrei Rublev i khudoshniki ego kruga (1972). 
expressed goals of the state for some time. They have been, but certainly the movement has not been directed or even inspired, let alone controlled, by the party. From time to time one has seen hints in the Soviet press that not all aspects of the search for the past were to be regarded with equanimity. Efim Dorosh has mocked the faddish aspects in Novyi mir (1969, no. 3), and another critic writing in the same journal, I. Dedkov, has been highly critical of the literary movement that seeks to find Russia's essence in the countryside, particularly the countryside of the past. Referring to the prose of such derevenshchiki as V. Astafiev, V. Belov, Iu. Galkin, V. Likhonosov, S. Meleshin, V. Potanin, E. Safonov, and V. Shukshin, Dedkov writes:

Current "rural" prose, at any rate that typified by its most widely read representatives, ... . strives to talk about the permanent and indisputable, about the composition and moral bases of the life of the contemporary peasant, about his outlook on life, his character and life style. In the artistic world of the best works of this type the modern peasant becomes the center, the axis, the subject of the reality being depicted, and everything else is set around the periphery in accordance with its true value for him. ... The idealization of the man of the countryside in literature and criticism, the justification of negative aspects of his character, social behavior, and position by the circumstances of life, doom us to repeat the unforgettable starry-eyed idealism of our not so distant precursors for whom Chekhov and Bunin were cruel and dismal portrayers of the peasant.12

The "rural" movement is very much part of the larger search for Russia's past, as the prose and poetry of those whom Dedkov names (see above) will show.

Criticism has also come from another level. In the May 6, 1969, issue of Sovetskaia Rossiia, in a long article entitled "Let's Talk About Tourism," one V. Petrov notes the vast outlay in time and material resources devoted to the restoration and reconstruction of historical and cultural monuments. But he detects certain shortcomings in the general planning for tourists, which is the chief reason for such expenditures according to Petrov: "The first of these is that a certain 'church bias' prevails in showing our sights." Petrov denies that church architecture, icons, and religious frescoes are the major cultural achievements of the Russian people. He says, "The excessive enthusiasm for gold cupolas works to the detriment of showing what our Russia has achieved in fifty years of Soviet power." Petrov recommends more tours of socialist institutions such as collective farms and factories and more monuments and displays concerning the Revolution and Civil War.

12. I. Dedkov, "Stranitsy derevenskoi zhizni (Polemicheskie zametki)," Novyi mir, 1969, no. 3, pp. $232,242$. 
Four days later Pravda contained an article by Iu. Kornilov on tourism in Suzdal. Indirectly refuting Petrov, Kornilov concludes that the restoration of the cultural and historical monuments of Russia's past is a good thing: "A little time will pass and the dreams of the forefathers of this city's present inhabitants will come true, forefathers who in their pride fought for primacy with Kiev, Moscow, and Vladimir, seeking greater glory for the city of Suzdal. But it, this glory, has now come to the city not through the force of arms but through the lasting power of the Russian people's art."

Despite the fact that the culturalist movement embraces all the arts and many other disciplines as well, the main arena for the discussion of the revival of interest in Russia's past has been the literary journals, in particular Molodaia gvardiia and Novyi mir. The latter published Efim Dorosh's "Reflections in Zagorsk" (from the book The Distant Past with Us) in 1967; the former printed Soloukhin's "Letters from a Russian Museum" (1965, nos. 9, 10) and has featured a column entitled "Preserve Our Sacred Relics" ("Beregite nashu sviatiniu") on an irregular basis since the mid-sixties. Molodaia gvardiia quickly became identified with the extreme position in the movement to revive "Holy Russia," a position that sought to cultivate a Great Russian patriotism at the expense of "proletarian internationalism" and "Soviet patriotism." As Innost put it, Molodaia gvardiia came to espouse an increasingly shrill "Russian chauvinism."13

In 1968 Molodaia gvardiia published two long articles by Viktor Chalmaev which opened a very lively, often vitriolic, polemic on Russian historical culture and Great Russian chauvinism. ${ }^{14}$ Chalmaev's first article, entitled "Great Strivings," sought to link Maxim Gorky as the spiritual founder of "socialist realism" with the search for the Russian soul, which is Chalmaev's chief concern. Chalmaev's method, culling quotations from the early writings of Gorky to advance his argument, and his real concern are clear from the following two examples taken from "Great Strivings": "In the story The Master Gorky says of the thirst for goodness in the people: 'it will appear from somewhere, envelop in kindness and illuminate harsh, dark life.' But weren't John of Kronshtadt, Nil Sarovsky [sic!], and other, more minor 'saints' and righteous men in Russia born with this same expectancy of a 'miracle,' of tender goodness?"15 Chalmaev goes on to evoke the lyricism of Bunin, Kuprin, and Rakhmaninov as an expression of the Russian soul. Near the end of this rather unconvincing attempt to make Gorky into a latter-day Slavophile, Chalmaev discovers that "in general Gorky in his tramps and merchants (Ignatii and Foma Gordeev,

13. Iunost', 1968, no. 2 , p. 99.

14. V. Chalmaev, "Velikie iskaniia," Molodaia gvardiia, 1968, no. 3, pp. 270-95, and “Neizbezhnost'," Molodaia gvardiia, 1968, no. 9, pp. 259-89.

15. Chalmaev, "Velikie iskaniia," p. 278. 
Bulychov, and others) uncovered one historically shaped characteristic of the Russian national character-an internally inherent and continual development, a 'fluidity,' some kind of uncontrollable pagan freedom."'16

This pseudo-mystical approach to Russian culture is continued and expanded in a second article published six months later. Entitled "Inevitability," it begins simply, "The sensation of a journey...." What follows is a wandering trip through Russian history from the seventeenth century to the revolutionary years of the twentieth, the point of which is to indicate to the Communist youth for whom Chalmaev is writing "the most essential contours of the spiritual process, [for] it is necessary to have an orientation in the areas of both native and world culture."

Decrying the debasing of the Russian language in the twentieth century ("the identification of the word not with the highest manifestations of the spirit but with the bazaar, with mundane life"), Chalmaev "discovers" Juraj Križanić, whose comments on Russia's chuzhebesie, or impassioned attraction to all that is alien, and total inability to practice restraint in anything are found applicable to a Soviet youth in danger of becoming "transistorized." Chalmaev asserts that despite Križaničs acute observations "there are mighty sources in the Russian national character-the feeling of social justice, patriotism, bravery, and also the search for truth and conscientiousness-which overcome chuzhebesie and chuzhevladstvo [foreign rule]."17 Avvakum, Nikon, Stepan Razin, Erofei Khabarov, and even Tsar Alexei Mikhailovich are found to be suitable heroes for twentieth-century youth:

And the boyarina Fedosiia Morozova, Avvakum's associate, carried off on a cart through the blue Moscow snow, in some mysterious way turns out to be related in strength of spirit and will, and fidelity to her idea, to the eagles of Peter's nest. Nikon, Avvakum, Morozova, Khabarov, and in his own way Razin personify that civilization of the soul determinedly coming to Rus'. They, and those "dark people" known to them, developed in themselves during that externally peaceful epoch such moral strength as would suffice later in excess for an epoch especially militant and active. ... Once in a century the Russian people are faced with a Poltava or Stalingrad defense, but the centuries prepare it for the event.... And even the religious energy of the Russian man not always but very frequently was diverted in the past to a military deed, to creative inspiration, that is, it was turned to aims totally unreligious. ${ }^{18}$

Soon Chalmaev is talking about the tendency in the present-day Soviet Union for the "mob," his term for the degenerate bourgeois "people," to triumph

16. Ibid., p. 293.

17. Chalmaev, "Neizbezhnost"," p. 264.

18. Ibid., pp. 267-68. 
over the pristine "people" (narod). To one's great surprise Konstantin Leontiev, "a friend of L. N. Tolstoy" and the "Chaadaev of the 60s-80s," turns up as Chalmaev's authority for such a negative transformation! Chalmaev is sincerely and rightly opposed to the "tourist bureau" tendency to assign a price tag to Russian culture-the restaurant before the restoration, as he puts it. He cannot but remind one of the lesser Slavophiles in his search for the broad Russian soul, however; and the mystical language and shadowy heroes whose spirit he summons must surely surprise readers of Molodaia gvardiia, the official journal of the Komsomol. One detects precious little of proletarian internationalism and no Soviet, as opposed to Russian, patriotism in his writings, which of course is precisely why Iunost' criticized Molodaia gvardiia.

Chalmaev's "position papers" were immediately the subject of an intense debate in other literary journals. He was sharply criticized by Iurii Surovtsev in an article that appeared in Literaturnaia Rossiia (November 7, 1968). Part of Surovtsev's criticism concerned the factual nature of Chalmaev's articleshis reliance on such unworthies as Leontiev, his misrepresentation of Nekrasov, and his sins of omission (no mention of such revolutionary heroes as Pestel and Chernyshevsky). But Surovtsev is much more to the point when he attacks Chalmaev's mystical emotional tone. He rightly asks what Chalmaev means by these threatening words which gave him the title for his article: "But there shall be a popular and not only an intellectual stage in the renaissance of the best of the people's traditions. This is the inevitability of our time."10 Surovtsev wonders whether the editorial board of Molodaia gvardiia is really convinced that "Nikon and the old believers, the evening ringing of church bells and the speechless little horse Savrasushka, the destruction of 'journalistic style,' and together with it cost accounting will foster genuinely patriotic, communistic upbringing of youth."20

Molodaia gvardiia answered Surovtsev in the February 1969 issue with an article by Anatolii Lanshchikov. Lanshchikov disputes Surovtsev's charge that Molodaia gvardiia and Chalmaev espouse "asocial" views, and he contends that although Chalmaev may not have written the most convincing article, nonetheless his intentions were pure; his method but not his aim is subject to criticism.

In March and April 1969 Novyi mir entered the discussion with two articles in which Chalmaev is directly attacked and one which is a "position paper" occupying a middle ground in the dispute. The latter is the previously mentioned article by Efim Dorosh, "Images of Russia," in which the author points out the great achievements of modern Soviet scholars in the study of

19. Iurii Surovtsev, "Pridumannaia neizbezhnost'," Literaturnaia Rossiia, Nov. 7, 1968, p. 17, quoting Chalmaev, "Neizbezhnost'," p. 281.

20. Surovtsev, "Pridumannaia neizbezhnost'," p. 17. 
Old Russian culture. Dorosh criticizes the fashionableness of the study of Old Russian culture-the naive and trite aspects of the movement. He criticizes the use of Church Slavonicisms and archaisms in the language, but also the general ignorance of the Russian population about its distant past. He notes somewhat ironically that modern Soviet youth tends to regard Russia as essentially a rural, peasant land whereas the Scandinavians of the ninth century referred to it as the land of cities. Dorosh takes the attitude that Old Russia was a land of many things and that although a love and affection for the true accomplishments of the creators of Russian culture is desirable, mysticism, emotion, and chauvinism are not.

The same March issue contained the article by Dedkov, "Pages of Rural Life: Polemic Notes." Dedkov's ostensible theme is the prose of the modern derevenshchiki, whose chief concern has been rural Russia. He writes-one imagines with tongue in cheek-of Chalmaev's "philosophy of patriotism":

It embraces "the extraordinary heroes of our native folklore-Ivan the Fool and Petrushka-," the cock's crow and the taste of Vologda cranberries, ... the works of Archpriest Avvakum and P. Ia. Chaadaev, and also the "intoxication of the people's soul" and its indisputable superiority over all other living souls of the earth, and in general [it embraces] all Russia with her greatness present and greatness past-up to 1917. There is a monopoly on the trade in vodka and tobacco, in truth there is a monopoly on patriotism. Pretentiousness of just this sort appears before us now. ${ }^{21}$

Dedkov goes on to quote the poet Valentin Sidorov, who said, "That window (referring to Peter the Great's activities) was more necessary for Europe than for us." In his criticism of Chalmaev's "philosophy of patriotism" Dedkov mentions Slavophilism but notes that the two movements are scarcely similar, for Slavophilism was a "serious, really original, and carefully thought out ideological movement."

The frontal assault on the philosophy of patriotism was made by the experienced polemicist and well-known critic A. Dementiev in the April issue of Novyi mir. Dementiev's article was written in the light of Anatolii Lanshchikov's and A. Metchenko's defenses of Chalmaev, appearing in Molodaia gvardiia and Moskva respectively. ${ }^{22}$ The main target remains Chalmaev. Dementiev repeats Chalmaev's factual errors and his concern with the appear-

21. Dedkov, "Stranitsy derevenskoi zhizni," pp. 231-32.

22. Anatolii Lanshchikov, "Ostorozhno-kontseptsiia! (Polemicheskie zametki)," Molodaia gvardiia, 1969, no. 2, pp. 275-97, esp. pp. 280-89; A. Metchenko, "Sovremennoe i vechnoe," Moskva, 1969, no. 1, pp. 198-211, esp. pp. 202-6. For Dementiev's article see A. Dement'ev, "O traditsiiakh i narodnosti (Literaturnye zametki)," Novyi mir, 1969, no. 4, pp. 215-35. 
ance in Soviet life of "a cult of satiety," "transistorized melodies," "cheap fashions," and "barbarity in a cellophane wrapper." But Dementiev's real concern is not with such trivia. He attacks Chalmaev for referring with praise to John of Kronshtadt and St. Seraphim of Sarov (the "Nil Sarovsky" of Chalmaev's article evidently amalgamates him with Nil Sorsky) while failing to mention the heroes of 1905 and 1917-particularly in the first article, where the subject was Gorky and the workers' heroes were appropriate to the theme. Dementiev carefully dissects Chalmaev's view of Russian history and finds it more similar to Slavophilism and nineteenth-century populism than to views acceptable at the present time. He agrees with Chalmaev that too much of Russia's cultural heritage has been disregarded for too long, mentioning the music of Skriabin and Stravinsky and the art of Vrubel, Kustodiev, and Maliavin among others, but he deplores Chalmaev's tendency to exclude revolutionary art from the nation's cultural achievements.

Dementiev has other targets besides Chalmaev, who, though spokesman of this movement, is not its most articulate member. In Dementiev's view it is Molodaia gvardiia that is at fault for fostering chauvinism by printing the works of such writers as the critic Lobanov, prose writer Sergei Vysotsky, and poets such as Valentin Sorokin, Vladimir Kotov, and Valentin Sidorovall of whom, in Dementiev's opinion, are adherents to this neo-Slavophile philosophy. Dementiev's criticism is sharp, and to those who have read Molodaia gvardiia over the past several years it rings substantially true. There has been in the criticism, poetry, and to some extent in the prose an intense patriotism, if not Great Russian chauvinism. It is unquestionably offensive to much of the cosmopolitan, urbane society of Moscow, which makes up a large part of the Soviet establishment. It is doubly so to the other national groups inhabiting the Soviet Union for whom such displays of nationalistic zeal are out of the question or at least are exceedingly risky. But probably Dementiev himself was unprepared for the response to his article.

It appeared as an open letter to the editors of Ogonek (July 26, 1969) and was signed by a group of eleven Soviet writers. ${ }^{23}$ The letter, printed under the headline "Against What Is Novyi mir Protesting?," is a slashing personal attack on Dementiev and a caustic condemnation of Novyi mir combined with lavish praise for Molodaia gvardiia and somewhat begrudging recognition that Chalmaev's articles suffered from certain shortcomings of fact but not of purpose. By linking Novyi mir's publication of Dementiev's article with the earlier publication of Andrei Siniavsky's critical works and by stating that Novyi mir espouses an editorial stance that "cultivates a skeptical view of the

23. Mikhail Alekseev, Sergei Vikulov, Sergei Voronin, Vitalii Zakrutkin, Anatolii Ivanov, Sergei Malashkin, Alexander Prokofiev, Peter Proskurin, Sergei Smirnov, Vladimir Chivilikhin, and Nikolai Shundik. 
social-moral values of Soviet society," the authors of the letter cast a shadow on Novyi mir's patriotism and faithfulness to the Soviet Union. Novyi mir's brief reply $(1969$, no. 7$)$ simply rejected the charges and denounced the authors of the letter for their attempts to "denigrate one of the oldest Soviet journals, attempts bordering on political discrimination." But Dementiev was removed from his position as assistant editor of Novyi mir soon thereafter. Thus the debate ended, inconclusively it would seem, for Molodaia gvardiia continues to publish its culturalist writers, and Novyi mir continues to ignore them. ${ }^{24}$

One wonders just what is behind this movement to "rediscover" the mythical Russian soul. Probably one cannot give any very complete and at the same time convincing explanations, but it is possible to suggest several directions in which they might lie.

For the scholarly interest one need offer no explanation. In every case it has been senior scholars, often trained before 1917, who have kept alive prerevolutionary traditions. And the remarkable group of younger men and women are in turn the protégés of those who preserved the best of Russia's academic traditions during the years when what is now called "vulgar sociologizing" was the officially accepted method of scholarship. ${ }^{25}$

Yet if the scholarly interest in Old Russian culture represents an obvious extension of a solid tradition, turizm and the "philosophy of patriotism," the "rural" movement in literature, and other related phenomena, such as the All-Russian Voluntary Society for the Preservation of Monuments of History and Culture, are less apparently so. Participation in these organizations, indeed in various aspects of the entire culturalist movement, tends to come largely, although not exclusively, from youth. It appears to be centered in the relatively well-educated urban population and is not revolutionary but rather deeply conservative, seeking to preserve old values and to restore old traditions. No doubt many young people are genuinely interested in their heritage, and one can detect several reasons for this interest in historical Russia. From the pages of Molodaia grardiia it is clear that the disenchantment of Soviet youth

24. In the last eighteen months articles have appeared by Vasilii Belov ("Eshche raz - iazyke," Molodaia gvardiia, 1971, no. 6, pp. 270-71) and Sergei Vikulov ("O derevne i 'derevenshchikakh,'" Molodaia gvardiia, 1971, no. 6, pp. 276-77), poetry on culturalist themes by Vikulov (Molodaia gvardiia, 1972, no. 6, pp. 13-19), and an extremely favorable review of the latest volume of the culturalist poet Nikolai Rubtsov, Zelenye tsvety, published posthumously in 1971 and reviewed by M. Lobanov in Molodaia gvardiia, 1972, no. 6 , pp. 290-95.

25. On the study of Old Russian literature since 1917 see Ia. S. Lur'e, "Drevnerusskaia literatura," in V. G. Bazanov, ed., Sovetskoe literaturovedenie za 50 let (Leningrad, 1968). The introduction to this book by G. M. Fridlender covers literature and the arts in general. The work is remarkable for the openness with which it discusses the problems faced by scholars and writers from time to time in the Soviet Union. 
with the increasing industrialization and pollution, destruction of irreplaceable natural resources, and so forth, has spawned something akin to the ecology movement in the United States. The poets speak of the contrast between asphalt and birch trees, openly preferring the latter. They speak despairingly of the pollution of Lake Baikal, of the destruction of ancient churches, and of the building of restaurants and hotels which detract from the architectural unity of Suzdal or the Moscow Kremlin. They speak of the death of the spiritcrushed by what they feel is a banal, commercial, and bourgeois attitude toward the nation's cultural tradition. The city with its concrete parks and housing projects is a symbol of all that is odious. Thus they flee romantically to the countryside and to the past.

At its best the culturalist movement has accomplished a great deal already, although it is impossible to know the full extent of the achievement. Much of what has been done was undertaken privately and quietly. But certainly, the organizers of the Rublev Museum in Moscow, the Madrigals led by Andrei Volkonsky, and those such as Vladimir Soloukhin who have succeeded in preserving many old icons seemingly doomed to destruction have managed much. The excesses of patriotism expressed by Viktor Chalmaev and the romanticization of village life by the derevenshchiki are probably just that, and they have been dealt with critically, but openly.

Is it possible that this movement has provided a cover for political and philosophical opposition to official dogma that would otherwise not be tolerated in the Soviet state? This is a difficult question to answer, but there is some evidence that the re-emergence of vigorous Russian nationalism has gone hand in hand with an increasing interest in religion. Certainly on some levels the interest has been more or less academic, ${ }^{26}$ but one can also see that the mystical search for Russia's national soul is often accompanied by an equally sincere search for Russian Orthodoxy's soul. Volkonsky's interest in church music, and the wide interest in old literature, art, and architecture, can perhaps be explained as professional in origin, but some recent poetry and prose give one the impression that the "philosophy of patriotism" is used to express some very personal, deep religious convictions. Soloukhin's "Chernye doski" is a case in point. He offers the following explanation for his interest in icons:

Of course icons can be looked at in two ways, and one's attitude towards them will differ accordingly. On the one hand an icon is an object of piety, a part of religious life, an accompaniment to devotion and ritual; on the other it is a work of art, a painting of historical value and national importance. Confusion between these two points of view has led to the

26. One might note the excellent works by A. I. Klibanov in this connection, particularly his Istoriia religioznogo sektantstva v. Rossii (60-e gody XIX v.-1917 g.) (Moscow, 1965). 
destruction of a vast number of icons-an especially sad loss because it is irreparable. . . . As for myself, while I was not a fervent enemy of icons, I was naturally not a protector of them either. As a Pioneer, why should I have been? The question did not arise in my mind one way or the other. That part of my consciousness-call it brain or soul as you will-which might in theory have reacted to icons and determined my attitude towards them was to all appearances switched-off, frozen, anaesthetised. ${ }^{27}$

But his interest seems much more than that of the avid collector. "Chernye doski" is full of allegorical and symbolic passages that give the reader the impression that Soloukhin's interest in icons is at least in part a portion of the writer's personal quest for self. He quotes the peasant woman Zakharova:

"How do you tell between light and darkness? When there was a monastery and a church here, and we used to decorate the icon [of the Resurrection] with flowers-do you think the village was a darker place then? You're mistaken, my young friends. The icon came down to us from the bright days of antiquity, and now, as you can see, it's been swallowed up by the darkness of ignorance. And here are you two young men looking for it -why? Because the icon is a light and a flame, drawing you to itself."28

A few paragraphs later Soloukhin carefully makes the following comment about the icon, "The Resurrection": "But I could not forget the vision of the Resurrection icon with its bright colours, now lost to view or even destroyed, as the old woman had put it, by the darkness of ignorance, but which, if she was right, would continue to beckon like a flickering flame."20

Soloukhin is certainly not alone. Literaturnaia Rossiia published a poem by Irina Ozerova in which she wrote:

Here is a Bible with Doré's engravings,

An immense tome long, long ago worn out from use.

But in it today just as in a primer

I seek the alphabet of eternal truths. ${ }^{30}$

That this interest in religion is of concern to the state can be seen from a spate of articles that appeared during the autumn of 1971. Leningradskaia pravda (September 8) noted with dismay the increasing number of church ceremonies, particularly christenings and weddings. Komsomol'skaia pravda (September 3 ) warned against the pervasive influence of Christian, humanist ideology on

27. Vladimir Soloukhin, Searching for Icons in Russia, trans. P. S. Falla (New York, 1971), pp. 13-14. This is the English translation of his "Chernye doski" ("Black Boards").

28. Ibid., p. 73.

29. Ibid., p. 74.

30. Literaturnaia Rossiia, Mar. 17, 1967. See also the poem by Rimma Kozakova published in Smena, 1967, no. 1, and the one by Valentin Sidorov, "Sluchai na vystavke," in Molodaia gvardiia, 1967, no. 8, pp. 63-64. 
Soviet youth. The link between the increasing interest in Christianity among Russian youth and the culturalist movement was provided by Literaturnaia Rossiia (October 22, 1971), which mentioned recent films (no doubt including Andrei Rublev) that portray the church and Christianity sympathetically. The paper went on to note that "on the beach during the summer one can see young men and women with crosses on their chests. Who are they? Believers? No. This is also in its own way a demonstration of devotion to that which is 'really' Russian."

Much of what adherents to culturalism say and do is obviously not at variance with the official dogmas of Soviet orthodoxy. But for the rest, for those seeking a mystical, religious significance in Russia's past and thus rejecting Soviet reality, there is an obvious conflict with the pronounced doctrine. In contemplating the future of the movement and of those whose spiritual search may lead it into conflict with the state, one is reminded of Nicholas Berdiaev's statement (and he, too, is now much quoted by Soviet youth) in another context: "All spirit must be at enmity with anything which prima facie deserves the name of revolution, and because, in general, revolution of the spirit opposes the spirit of revolution." 11

31. Nicholas Berdyaev, Dostoevsky, trans. Donald Attwater (Cleveland and New York, 1969), p. 136. 